\title{
The chemical composition, energy and amino acid digestibility of cowpeas used in poultry nutrition
}

\author{
N.J. Tshovhote ${ }^{\#}$, A.E. Nesamvuni, T. Raphulu and R.M. Gous ${ }^{1}$ \\ Department of Animal Science, School of Agriculture, Rural Development \& Forestry, University of Venda for Science \\ \& Technology, P/Bag X5050, Thohoyandou 0950, South Africa \\ ${ }^{1}$ School of Agricultural Sciences \& Agribusiness, Faculty of Science \& Agriculture, University of Natal, \\ Pietermaritzburg 3209, South Africa
}

\begin{abstract}
The aim of this study was to determine the chemical composition and digestibility of cowpeas for use in poultry diets. Three cowpea cultivars, Glenda, Agrinawa and Indigenous were evaluated. The cultivars showed a relatively narrow range of protein concentrations $(253.5$ to $264.3 \mathrm{~g} / \mathrm{kg})$. The concentrations of amino acids (AA) varied among the cultivars. Dietary crude fibre levels varied from 51.5 to $58.1 \mathrm{~g} / \mathrm{kg}$. The cultivars were almost devoid of lipid and calcium, but were relatively high in phosphorus. The apparent and true metabolisable energy $\left(\mathrm{AME}_{\mathrm{n}}\right.$ and $\mathrm{TME}_{\mathrm{n}}$ ) values ranged from 9.88 to 10.02 and 10.29 to $10.78 \mathrm{MJ} / \mathrm{kg}$ $\mathrm{DM}$, respectively. The mean digestibilities of the AA's ranged from 72.8 to $81.0 \%$, with methionine having the highest digestibility and lysine the lowest. Cowpeas appear to be suitable for use in poultry feeds, their composition being equivalent to plant protein sources such as lupins and field peas, but lower in most nutrients compared with soybeans and canola.
\end{abstract}

Keywords: Cowpeas, chemical composition, amino acid digestibility, poultry

\# Corresponding author. E-mail: ndiafhi@univen.ac.za

\section{Introduction}

The cowpea (Vigna unguiculata) is an important grain legume in tropical and subtropical regions where a shortage of animal protein sources is often experienced. Cowpeas are heat- and drought- tolerant crops (Apata \& Ologhobo, 1997), requiring low input costs and are well adapted to the arid agronomic areas of South Africa (Nell et al.,1992). Cowpeas as well as other peas can be excellent sources of dietary protein in animal nutrition (Igbasan \& Guenter, 1997), especially where animal proteins are in short supply and expensive (Wiryawan \& Dingle, 1995). The nutrient and energy concentrations of peas compare well with those of soya beans, with similar amino acid profiles (Ravindran \& Blair, 1992), and are often less expensive. Although the protein level of cowpeas shows great variation (Canon \& Carre, 1989), they can offer an alternative to lipid extracted soya oilcake meal. The variation in protein level that is observed within species may be attributed to differences in genotypic and environmental factors, as well as to agronomic practices (Ali-khan \& Youngs, 1973). Cowpeas are characteristically low in sulphur containing amino acids and high in lysine (Coertze \& Venter, 1996). Similar to other grain legumes, cowpea seeds contain some non-digestible and anti-nutrient factors (Igbasan \& Guenter, 1997). These include protease inhibitors, nonstarch polysaccharides (NSP), pectins and phenolic compounds (Arora, 1995), which reduce protein quality and nutrient digestibility. Protease inhibitors impair the activity of pancreatic enzymes such as trypsin and chymotrypsin.

Nutritionists and feed manufacturers require accurate nutrient information of specific cowpea cultivars to formulate the balanced diets containing these peas. Plant breeders also need such information to enable them to develop better varieties to improve the nutritional value of the seeds. The objective of this study was to evaluate the chemical composition, energy and amino acid digestibility of cowpeas in poultry diets.

\section{Materials and Methods}

Three cultivars of cowpeas, Glenda, Agrinawa and an indigenous cultivar (Indigenous) were evaluated in this study. All seeds were dried, dehulled and ground to pass through a $1 \mathrm{~mm}$ sieve for chemical analysis. Samples were analysed for moisture from which dry matter (DM) content was calculated. Crude protein was determined with a LECO FP2000 Nitrogen Analyser, based on the Dumas combustion method; crude fibre, lipid, calcium and phosphorus concentrations were determined by standard methods of analysis 
(AOAC, 1990). Amino acids (AA) concentrations were obtained, using the AA analyser (Beckman System 6300, Palo Alto, California, USA). An adiabatic bomb calorimeter (DDS CP500, South Africa) was used to measure gross energy of the cowpeas and excreta from the digestibility study. Condensed tannins were determined as described by Porter et al. (1986).

The digestibility trial was conducted with 48 adult Leghorn cockerels, which were divided into four groups of 12 birds each. Three groups were fed the different cowpea cultivars and the fourth was fed a glucose solution. The precision feeding technique described by McNab \& Fisher (1984) was used to determine the nitrogen corrected apparent and true metabolisable energy ( $\mathrm{AME}_{\mathrm{n}}$ and $\mathrm{TME}_{\mathrm{n}}$, respectively) values and the true amino acid digestibility (TDAA) of the samples. After a 48-h fasting period, during which $50 \mathrm{~g}$ glucose in solution was fed to each bird, $50 \mathrm{~g}$ of each cowpea cultivar was precision fed by intubation to three groups of six birds housed in individual cages in an environmentally controlled house. After $48 \mathrm{~h}$ all the excreta from each bird were collected, dried in a force draught oven at $90{ }^{\circ} \mathrm{C}$, milled to pass through a $1 \mathrm{~mm}$ sieve and analysed for gross energy, nitrogen (determined with a LECO FP2000 Nitrogen Analyser, based on the Dumas combustion method) and AA concentrations.

The $\mathrm{AME}_{\mathrm{n}}, \mathrm{TME}_{\mathrm{n}}$ and TDAA values were calculated according to methods described by McNab \& Fisher (1984). The endogenous energy losses and nitrogen and amino acid values used in calculations were obtained from the pooled data for 12 birds treated in the same way as the precision fed birds, but fed $50 \mathrm{~g}$ glucose $48 \mathrm{~h}$ after being fasted. The $\mathrm{AME}_{\mathrm{n}}, \mathrm{TME}_{\mathrm{n}}$ and TDAA values for each pea sample were determined in duplicate and each duplicate value represented a pooled determination from six birds.

Data were subjected to an analysis of variance using the General Linear Model (GLM) procedure of SAS (1986). The differences between the cultivar means were tested for significance at $\mathrm{P} \leq 0.05$.

\section{Results and discussion}

The chemical composition of the cowpea cultivars is presented in Table 1. The DM content ranged between 901.5 and $907 \mathrm{~g} / \mathrm{kg}$. The protein concentration was highest in Indigenous cowpea $(264.3 \mathrm{~g} / \mathrm{kg})$, followed by Agrinawa $(257.6 \mathrm{~g} / \mathrm{kg}$ ) and Glenda $(253.5 \mathrm{~g} / \mathrm{kg})$. These protein contents are similar to those of canola $(244 \mathrm{~g} / \mathrm{kg})$ and field peas $(230 \mathrm{~g} / \mathrm{kg})$, but lower than is common in unextracted soybeans and lupins $(370 \mathrm{~g} / \mathrm{kg})$. The dietary fibre level was highest in Glenda $(58.1 \mathrm{~g} / \mathrm{kg})$ and lowest in the Indigenous cultivar $(51.5 \mathrm{~g} / \mathrm{kg})$. The variation in chemical composition could be a reflection of the conditions under which they were grown, or could be due to inherent genetic differences. Protein concentration is known to vary with soil type and nitrogen fertilizer application (Igbasan \& Guenter, 1996), genotypes (Matthews \& Arthur, 1985), location and year of harvest (Ali-khan \& Youngs, 1973; Nell et al., 1992).

These cultivars were almost devoid of lipid and calcium but were high in phosphorus $(3.86,3.77$ and $4.22 \mathrm{~g} / \mathrm{kg}$ DM for Indigenous, Agrinawa and Glenda, respectively). The cowpeas contained high levels of phytate, which negatively affects the digestibility of phosphorus (Igbasan et al., 1984; Apata, 1990; D'Mello, 1995). The Indigenous cowpea contained the highest concentration of unextractable condensed tannins (8.71\% DM) compared to the Agrinawa and Glenda cultivars (Table 2). The analysed starch level of Indigenous cowpea was $316 \mathrm{~g} / \mathrm{kg} \mathrm{DM}$. Two fractions of starch, amylose and amylopectin, were determined. Phytate concentration in the Indigenous cowpea is also presented in Table 2. Cowpeas can serve as a source of phosphorus to broilers, provided the enzyme, phytase, is added, since the seeds contained $1.55 \mathrm{~g}$ phytate $/ \mathrm{kg}$ DM (Table 2). This is lower than the 2.8 - 3.3 g phytate $/ \mathrm{kg}$, reported by Ologhobo \& Fetuga (1984).

The three cultivars had very similar $\mathrm{AME}_{\mathrm{n}}$ values, with Agrinawa having the highest and the Indigenous variety the lowest value (Table 1). The $\mathrm{AME}_{\mathrm{n}}$ values ranged from 9.88 to $10.02 \mathrm{MJ} / \mathrm{kg} \mathrm{DM}$, being considerably lower than the values for unextracted soybeans $(14.1 \mathrm{MJ} / \mathrm{kg})$, canola $(18.1 \mathrm{MJ} / \mathrm{kg})$ and field peas $(11.1 \mathrm{MJ} / \mathrm{kg})$, but in the same range as lupins $(10.5 \mathrm{MJ} / \mathrm{kg})$. The $\mathrm{AME}_{\mathrm{n}}(\mathrm{MJ} / \mathrm{kg})$ values of the three cowpea cultivars were lower than those reported for cowpeas by Igbasan \& Guenter (1996). The values obtained in this study are fairly comparable to those reported by Simon (1999), which ranged from 9.5 to $13.1 \mathrm{MJ} / \mathrm{kg} \mathrm{DM}$. The $\mathrm{AME}_{\mathrm{n}}$ and $\mathrm{TME}_{\mathrm{n}}$ values obtained are in agreement with those reported by Brenes et al. (1993), who observed a reduction of $13.6 \%$ in $\mathrm{AME}_{\mathrm{n}}$ value when cowpeas were fed to growing chicks in concentrations up to $500 \mathrm{~g} / \mathrm{kg}$ diet. Canon \& Carré (1989) observed reductions of about 8.8, 3.4 and 7.7\% in the $\mathrm{AME}_{\mathrm{n}}$, apparent protein and starch digestibility respectively when diets containing $450 \mathrm{~g}$ peas $/ \mathrm{kg}$ were fed to broilers. However, the material may not pose the same problems at lower levels of inclusion. These reductions might be due to the presence of amylo-pectin and tannins found in the Indigenous cowpea, 
although these may not be the only factors responsible for low metabolisable energy values, since there are other anti-nutritional factors present (Longstaff \& $\mathrm{McNab}, 1987$ ). Variability in starch level and digestibility, and variable concentrations of anti-nutritional factors in the peas could be also the cause of low $\mathrm{AME}_{\mathrm{n}}$ and $\mathrm{TME}_{\mathrm{n}}$ values.

The amino acid composition of the three cultivars, and their digestibility values, are shown in Table 3. Similar to the trend of protein concentrations, there were also variations between the cultivars in AA concentrations. The concentrations of all amino acids other than methionine and tyrosine were higher in the Indigenous cowpea cultivar than in the other two cultivars. As with the characteristics of legume seeds, the varieties were high in lysine but low in the sulphur amino acid, methionine, compared to the requirements of broilers in the starter phase (Igbasan et al., 1997). The lysine content of the cowpeas used in this study was in the same range as that found in canola $(15.9 \mathrm{~g} / \mathrm{kg})$, field peas $(17 \mathrm{~g} / \mathrm{kg})$ and lupin $(18.0 \mathrm{~g} / \mathrm{kg})$, although lower than in unextracted soybeans $(24 \mathrm{~g} / \mathrm{kg})$. The methionine content was the same as in field peas and lupins $(2.0$ to $2.7 \mathrm{~g} / \mathrm{kg}$ ) but considerably lower than in soybeans or canola $(5.0$ and $3.8 \mathrm{~g} / \mathrm{kg}$ respectively).

The mean digestibility of different AA's ranged between 76.3 and $79.0 \%$, with methionine having the highest value and lysine the lowest. The lower overall amino acid digestibilities in the cowpea varieties Agrinawa and Glenda may be due to their relatively higher concentrations of unextractable condensed tannins, which decrease the digestibilities of protein and carbohydrates by forming insoluble enzymeresistant complexes. However, this should not preclude them from use in broiler feeds, as broilers were reported to tolerate up to $11.5 \mathrm{~g}$ tannin/kg DM (Nyamambi et al. (unpublished), cited by Ndlovu (2000)). Also, the high level of carbohydrates (amylose and amylopectin) may depress the digestibility of protein and starch as birds do not possess the enzymes that will degrade the $\alpha-1,6$ and $\beta$-linkages that combine the monomers of starch. The high lysine and leucine concentrations and low methionine concentration could be explained in terms of the AA composition of the storage proteins, the main storage proteins in peas being albumins and globulins (Casey, 1983; Gueguen \& Barbot, 1988). In the context of meeting the dietary requirements for essential AA for poultry, cereal grains are nutritionally complementary with grain legumes in that those amino acids lacking in one (low total sulphur amino acids in legumes and low lysine in cereals) are adequate in the other.

Table 1 Chemical composition ( $\mathrm{g} / \mathrm{kg}$ dry matter) of three commercial cowpea (Vigna unguiculata) cultivars

\begin{tabular}{lccc}
\hline & $\begin{array}{c}\text { Indigenous } \\
\text { Cowpea }\end{array}$ & Agrinawa & Glenda \\
\hline Dry matter & 907 & 902 & 901.5 \\
Crude protein & 264 & 258 & 253 \\
Lipid & 13.2 & 14.1 & 13.3 \\
Crude fibre & 51.5 & 57.2 & 58.1 \\
Calcium & 1.32 & 1.44 & 1.55 \\
Total phosphorus & 3.86 & 3.77 & 4.22 \\
$\mathrm{AME}_{\mathrm{n}}(\mathrm{MJ} / \mathrm{kg})$ & 9.88 & 10.37 & 10.02 \\
$\mathrm{TME}_{\mathrm{n}}(\mathrm{MJ} / \mathrm{kg})$ & 10.29 & 10.78 & 10.44 \\
\hline
\end{tabular}

Table 2 Anti-nutritional factors present in three commercial cowpea cultivars

\begin{tabular}{lccc}
\hline \multicolumn{1}{c}{ Cowpea cultivar } & \multicolumn{3}{c}{ Condensed tannins (\% DM) } \\
\hline Indigenous * & Extractable & Unextractable & Total \\
Agrinawa & 2.04 & 8.71 & 10.75 \\
Glenda & 5.90 & 3.63 & 9.53 \\
\hline
\end{tabular}

$*$ Phytate $=1.55 \mathrm{~g} / \mathrm{kg} \mathrm{DM}$ and starch $=316 \mathrm{~g} / \mathrm{kg} \mathrm{DM}$ 
Table 3 Total amino acid concentrations ( $\mathrm{g} / \mathrm{kg}$ dry matter) and their digestibilities (\%) for the three commercial cowpea (Vigna unguiculata) cultivars

\begin{tabular}{ccccccc}
\hline & \multicolumn{2}{c}{ Indigenous } & \multicolumn{2}{c}{ Agrinawa } & \multicolumn{2}{c}{ Glenda } \\
Amino acid & Total & Digestibility & Total & Digestibility & Total & Digestibility \\
\hline Threonine & 0.86 & 78.3 & 0.84 & 71.1 & 0.84 & 74.9 \\
Valine & 1.27 & 78.3 & 1.19 & 70.4 & 1.24 & 75.2 \\
Metionine & 0.28 & 82.2 & 0.32 & 80.3 & 0.31 & 81.6 \\
Isoleucine & 1.12 & 77.8 & 1.06 & 70.4 & 1.01 & 73.6 \\
Leucine & 1.90 & 79.1 & 1.80 & 71.9 & 1.74 & 75.9 \\
Tyronine & 0.54 & 79.0 & 0.56 & 70.4 & 0.59 & 77.7 \\
Phenylanaline & 1.41 & 79.4 & 1.34 & 71.5 & 1.27 & 76.1 \\
Histidine & 0.79 & 76.5 & 0.75 & 72.0 & 0.74 & 75.2 \\
Lysine & 1.67 & 74.7 & 1.61 & 69.8 & 1.52 & 73.9 \\
Arginine & 1.77 & 83.0 & 1.65 & 75.1 & 1.52 & 78.0 \\
\hline Mean \pm s.d. & \multicolumn{7}{c}{$7.0 \pm 1.4 \pm 3.51$} & & $76.3 \pm 3.42$ \\
\hline
\end{tabular}

\section{Conclusions}

It is apparent from this study that the chemical composition of the three different cowpea cultivars varies considerably, and that the nutritional value of cowpeas is not as high as that of other plant protein sources such as unextracted soybeans, canola, lupins and field peas. The crude protein and ME contents of the three different cultivars were lower than in any of these alternative protein sources. The overall amino acid supply, and their digestibilities were higher in the Indigenous cowpea variety than in the other two varieties, with the lysine and methionine contents falling somewhere between the concentrations found in some of the other plant protein sources. The results from this study suggest that, where cowpeas can be grown locally, low input farming systems would benefit from the use of this source of protein for poultry feeds.

\section{References}

Ali-khan, S.T. \& Youngs, C.G., 1973. Variation in protein in field peas. Can. J. Plant Sci. 53, 37-41.

Apata, D.F., 1990. Biochemical, nutritional and toxicological assessment of some tropical legume seeds. $\mathrm{PhD}$ thesis, University of Ibadan.

Apata, D.F. \& Ologhobo, A.D., 1997. Trypsin inhibitor and other anti-nutritional factors in tropical legume seeds. Trop. Sci. 37, 52-59.

Arora, S.K., 1995. Composition of legume grains. In: Tropical legumes in animal nutrition. Eds. D'Mello, J.P.F. \& Devendra, C., Cab International, Wallingford, UK, pp. 67-93.

AOAC, 1990. Official methods of Analysis (15th ed.). Association of Official Analytical Chemists, Inc., Washington, D.C.

Brenes, A., Marquardt, R.R., Guenter, W. \& Rotter, B.A., 1993. Effect of enzyme supplementation on the nutritive value of raw, autoclaved and dehulled lupin (Lupinus albus) in chicken diets. Poult. Sci. 72, 1731-1739.

Casey, R., 1983. Genes for Pisum legumin. Perspectives for peas and lupines as protein crops. In: Proc. Int. Symp. protein production from legumes in Europe, Serrento and Italy. Eds. Thompson R. \& Casey, R., Martinus Nijhoff Publ., Dordrecht, The Netherlands. pp. 203-218.

Coertze, A.F. \& Venter, S., 1996. A.3 - Cowpeas. Indigenous seed crops, pp. 1-5. Agricultural Research Council.

Canon, L. \& Carré, B., 1989. Effect of autoclaving on the metabolisable energy value of smooth peas (Pisum Sativum) in growing chicks. Anim. Feed Sci. Technol. 26, 337-345.

D’Mello, J.P.F., 1995. Anti-nutritional substances in legume seeds. In: Tropical legumes in animal nutrition. Eds. D’Mello, J.P.F. \& Devendra, C., Cab International, Wallingford, UK, pp. 135-172.

Gueguen, J. \& Barbot, J., 1988. Quantitative and qualitative variability of pea (Pisum sativum L.) protein composition. J. Food Sci. Agric. 42, 209-224.

Heartland Lysine, Inc., 1995. Digestibility of essential amino acids for poultry and swine, Version 3.2. Heartland Lysine, Inc. Chicago, IL, USA. 
Igbasan, F.A. \& Guenter, W., 1996. The evaluation and enhancement of the nutritive value of yellow-, green and brown-seeded pea cultivars for unpelleted diets given to broiler chickens. Anim. Feed Sci. Technol. 63, 9-24.

Igbasan, F.A. \& Guenter, W., 1997. The influence of micronization, dehulling and enzyme supplementation on the nutritional value of peas for laying hens. Poult. Sci. 76, 331-337.

Igbasan, F.A., Guenter, W. \& Slominski, B.A., 1997. Field peas: chemical composition, energy and amino acid availabilities for poultry. Can. J. Anim. Sci. 77, 293-300.

Igbasan, F.A., Guenter, W., Slominski, B.A. \& Zhang, W., 1984. Alternative feed source for poultry diets: an evaluation of feed-type pea cultivars from western Canada. Poult. Sci. 73 (Suppl. 1), 9.

Jansman, A.J.M., 1993. Tannins in feedstuffs for simple-stomached animals. Nutr. Res. Rev. 6, 209-236.

Longstaff, M. \& McNab, J.M., 1987. Digestion of starch and fibre carbohydrates in peas by adult cockerels. Br. Poult. Sci. 28, 261-285.

McNab, J.M. \& Fisher, C., 1984. An assay for true and apparent metabolisable energy. In: Proc. XVII ${ }^{\text {th }}$ Wld.Poult. Congr., pp. 374-376

Matthews, P. \& Arthur, E., 1985. Genetic and environmental components of variation in protein content in peas. In: The pea crop. A basis for improvement. Eds. Hebblethwaite P.D., Health M.C. \& Dawkins, T.C.K., Butterworths, London, UK. pp. 369-381.

Nell, F.J., Siebrits, F.K. \& Hayes, J.P., 1992. Studies on the nutritive value of cowpeas (Vigna unguiculata). S. Afr. J. Anim. Sci. 22, 157-160.

Ndlovu, L.R., 2000. Tannins in animal agriculture: friend or foe? Proc. $38^{\text {th }}$ Nat. Congr. S. Afr. Soc. Anim. Sci., 51-52, Alpine Heath, Kwazulu-Natal, South Africa.

Ologhobo, A.D. \& Fetuga, B.L, 1984. Effect of processing on trypsin inhibitor, haemagglutinin, tannic acid and phytic acid contents of seeds of ten cowpea varieties. Trop. Agric. (Trinidad) 16, 201-264.

Porter, L.J., Harstich, L.N. \& Chan, B.G., 1986. The conversion of procyanidins and prodelphinidins to cyanidin and delphinidin. Phytochem. 25, 223-230.

Ravindran, V. \& Blair, R., 1992. Feed resources for poultry production in Asia and the Pacific. II. Plant protein sources. Wld. Poult. Sci. 48, 205-231.

SAS, 1986. Statistical Analysis Systems user's guide (1st ed.). Cary, NC. SAS Inc., 1986. pp. 336.

Simon, O., 1999. Feed raw materials. Part 2- The up and coming legumes. Feed Tech. 3, 29-33.

Wiryawan, K.G. \& Dingle, J.G., 1995. Screening tests of the protein quality of grain legumes for poultry production. Br. J. Nutr. 74, 671-679. 